\title{
Ferrous bisglycinate increased iron transportation through DMT1 and PepT1 in pig intestinal epithelial cells compared with ferrous sulphate
}

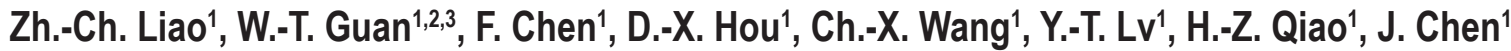 \\ and J.-H. $\operatorname{Han}^{1}$ \\ ${ }^{1}$ South China Agricultural University, College of Animal Science, Guangzhou 510642, China \\ ${ }^{2}$ National Engineering Research Center for Breeding Swine Industry, Guangzhou, 510642, China
}

KEY WORDS: epithelial cell, ferrous sulphate, ferrous bisglycinate, iron, DMT1, PepT1, intestine, pig

Received: 21 Nonember 2013

Revised: 11 April 2014

Accepted: 12 June 2014

${ }^{3}$ Corresponding author:

e-mail:wtguan@scau.edu.cn

\begin{abstract}
To study the different mechanisms of absorption of diverse iron sources, pig intestinal epithelial cells (IPEC) were incubated with various concentrations of ferrous sulphate and ferrous bisglycinate for different times to determine the expression of divalent metal transporter (DMT1), peptide transporter (PepT1), ferritin, transferrin receptor (TfR), and neutral amino acid transporter (ASCT1 and ASCT2) using RT-PCR and Western blotting. In the ferrous bisglycinate groups, the expression of DMT1 protein was higher at $24 \mathrm{~h}$ and a concentration of $1 \mathrm{mmol} \cdot H^{-1}(P<0.05)$ and expression of PepT1 protein was higher in all treatments $(P<0.05)$; expression of TfR and ferritin mRNA was higher at $36 \mathrm{~h}, 0.5 \mathrm{mmol} \cdot \mathrm{l}^{-1}$ and $1 \mathrm{mmol} \cdot \mathrm{l}^{-1}$; and $24 \mathrm{~h}, 1 \mathrm{mmol} \cdot \mathrm{l}^{-1} ; 36 \mathrm{~h}$, $0.5 \mathrm{mmol} \cdot \mathrm{H}^{-1}(P<0.05)$, respectively; ASCT1 and ASCT2 mRNA expression was higher at $36 \mathrm{~h}, 0.5 \mathrm{mmol} \cdot l^{-1}(P<0.05)$. We conclude that the more effective absorption of ferrous bisglycinate is associated with higher expression of iron-related transporters in IPEC cells.
\end{abstract}

\section{Introduction}

The iron consumed daily in grain may be absorbed in the form of iron ions or haeme iron (Andrews, 1999). Most of the iron in grain exists in the form of ferric ions $\left(\mathrm{Fe}^{3+}\right)$, which, because of their poor solubility in water, are poorly absorbed by intestinal epithelial cells. Ferric ion is transformed into soluble ferrous ions $\left(\mathrm{Fe}^{2+}\right)$ by cytochrome $b$ reductase (Dcytb) on the surface of duodenal epithelial cells before being absorbed (McKie et al., 2001). Iron is transported and penetrates the brush border membrane via divalent metal transporter (DMT1) (Fleming et al., 1997; Gunshin et al., 1997). In microcytic anaemia in the domestic mouse and Belgrade mice, changes in the DMT1 expression are indicative of the amount of iron absorption in the intestine (Fleming et al., 1998). In animals lacking DMT1 function, iron absorption from consumed grain is reduced, leading to microcytic anaemia. This indicates that DMT1 is the main iron transport protein in intestinal epithelial cells (Hubert and Hentze, 2002). Within cells, iron is stored in the form of 
ferritin, or transported through the basilar membrane via ferroportin. Iron transported out of the cell will be incorporated into ferroportin in the presence of oxidase transport protein, and distributed through the tissue with transferrin or absorbed into endosomes by combining with the transferrin receptor (TfR) (Ezquer et al., 2006). Iron homeostasis in the cell is regulated by many factors, including iron-related transporters, body iron stores, especially hepcidin, which plays a key role in down-regulating enterocyte iron absorption, thus affecting iron absorption and animal health (Starzynski et al., 2005; Lipinski et al., 2010). Deletion of the hepcidin gene causes massive iron loading in the liver (Nicolas et al., 2001), whereas overexpression of this gene results in severe anaemia (Nicolas et al., 2002).

In the animal industry, ferrous sulphate and amino acid-chelated iron are both widely supplemented to piglet feed to improve growth performance. A number of studies have been conducted to evaluate the iron absorption efficiency of these two mineral additives, but their conclusions vary. In several investigations, no differences were found between these two additives. A study conducted using Caco-2 cells as a model combined with the ${ }^{59} \mathrm{Fe}$ isotope tracer technique showed similar absorption of amino acidchelated iron and ferrous ascorbate (Mazariegos et al., 2004). Yeung et al. (2005) reported that the iron absorption of ferrous sulphate, ferric chloride, ferrous ascorbate, ferrous bisglycinate, ferric citrate, and the absorption channel for chelated $\mathrm{Fe}$ and inorganic salt are the same in the Caco-2 cell model (Yeung et al., 2005). However, some investigations indicated that the iron absorption rate of amino acid-chelated iron was higher than that of ferrous sulphate (Cocato et al., 2008; Ettle et al., 2008; Krasucki and Orlicki, 2008).

At present, ferrous bisglycinate is the most widely used additive in the pig industry. Previous studies interestingly suggested that the absorption of ferrous bisglycinate was greater than the absorption of ferrous sulphate (Fairweather-Tait et al., 1992; Pineda et al., 1994; Fox et al., 1998; Pineda and Ashmead, 2001). This may indicate that the iron absorption mechanism is not the same for ferrous bisglycinate and ferrous sulphate. Some studies considered that metal amino-acid chelates may be absorbed by other transporters, such as the intestinal peptide transporter (PepT1) (Ashmead, 1991; Lowe et al., 1994). After being released from ferrous bisglycinate, glycine is transported by an ASC-type transporter, the major transit mechanism for small, branched neutral amino acids (Kanai and Hediger, 1992; Pizarro et al., 2002). ASCT1 and ASCT2 are two subtypes of ASC that have similar substrate specificity and functional characteristics (Avissar et al., 2001).
Considering the increasingly wider use of amino acid-chelated iron in the pig industry, it is important to compare the absorption efficiency of ferrous sulphate and amino acid-chelated iron, and further, to reveal the underlying mechanism. Therefore, the aim of our study was to examine the influence of ferrous bisglycinate on the expression of iron transport components in pig intestinal epithelial cells and to identify the differences in the regulated transport pathways for ferrous bisglycinate and ferrous sulphate in these cells.

\section{Material and methods}

\section{Cells and reagents}

Pig intestinal epithelial cells (IPEC-1) were kindly provided by Professor Guoyao Wu from Texas A\&M University. Ferrous sulphate (analytically pure; ferrous content, 30\%) was obtained from Tianjin Damao Chemical Reagent Factory (Tianjin, China), and ferrous bisglycinate (iron content, 17\%) was obtained from the Shandong Heshi Group (Shandong, China). Ferrous solutions were prepared by dilution in double-distilled water and filtration $(0.22 \mu \mathrm{m}$; Millipore). Atomic absorption spectrometry (Varian $220 \mathrm{FS}$, US) was used to determine ion concentrations by the flame method before the solutions were stored at $-20^{\circ} \mathrm{C}$; mineralization was performed using dry digestion methods (Tam and Yao, 1999).

Cells were seeded $\left(2.0 \times 105\right.$ cells $\left.\cdot \mathrm{ml}^{-1}\right)$ in $25 \mathrm{~cm}^{2}$ culture dishes in DMEM-F12 (Life Technologies, Gaithersburg, MD, USA) with 5\% foetal calf serum (GIBCO, USA) and incubated at $37^{\circ} \mathrm{C}$. Medium was replaced every $24 \mathrm{~h}$. Cells were digested with $0.25 \%$ pancreatin for 3 min. Complete medium was added to achieve a cell density of $1.5 \times 105$ cells $\cdot \mathrm{ml}^{-1}$. Aliquots of cell suspensions $(0.95 \mathrm{ml}$ each $)$ were added to 6 -well plates with $0.05 \mathrm{ml}$ of varying concentrations of ferrous bisglycinate or ferrous sulphate to bring the final concentration of iron to be $0.5,1.0$ and $2.0 \mathrm{mmol} \cdot 1^{-1}$. Cultures were incubated for 12,24 , or $36 \mathrm{~h}$ before harvesting for analysis.

\section{RNA extraction and cDNA synthesis}

Total RNA was isolated with TRIzol reagent (Invitrogen, Carlsbad, CA, USA) and reverse-transcribed with dNTPs (TaKaRa, Japan) and M-MLV reverse transcriptase (Promega, USA). The quality of RNA was determined by calculating the OD 260/280 ratio using a spectrophotometer (NANODROP2000, Thermo Scientific, USA) and by agarose gel electrophoresis. 
Table 1. List of primer sequences

\begin{tabular}{|c|c|c|c|c|}
\hline Gene & $\begin{array}{l}\text { GenBank } \\
\text { accession No. }\end{array}$ & Primer sequences & $\begin{array}{l}\text { Amplicon length } \\
\text { bp }\end{array}$ & $\begin{array}{l}\text { Annealing } \\
\text { temperature }\end{array}$ \\
\hline ASCT1 & XM_003125088.2 & $\begin{array}{l}\text { F: AGCAAGATTGTGGAAATGAAGG } \\
\text { R: TGCAAATGGCGTGACGAG }\end{array}$ & 177 & 59 \\
\hline ASCT2 & DQ231578.1 & $\begin{array}{l}\text { F: CAAGATTGTGGAGATGGAGGAT } \\
\text { R: TTGCGAGTGAAGAGGAAGTAGAT }\end{array}$ & 132 & 58 \\
\hline DMT1 & EU647217.1 & $\begin{array}{l}\text { F: GAATGTTCCTGCCATCGTGTT } \\
\text { R: GCTTCTCGCACTTCCTCCTTAT }\end{array}$ & 160 & 60 \\
\hline PepT1 & AY180903.1 & $\begin{array}{l}\text { F: 5' TTCTGTTTGCGGGGTTGC 3' } \\
\text { R: 5' TGCGTCTGTACGTCGGTGTC 3' }\end{array}$ & 172 & 60 \\
\hline $18 S$ & NR_046261.1 & $\begin{array}{l}\text { F: ATTCCGATAACGAACGAACGAACGAGACT } \\
\text { R: GGACATCTAAGGGCATCACAG }\end{array}$ & 105 & 59 \\
\hline Ferritin & D15071.1 & $\begin{array}{l}\text { F: AACGAGGTGCCCGAATCTT } \\
\text { R: GTTCCAGCAGGGACTGATACAC }\end{array}$ & 126 & 59 \\
\hline
\end{tabular}

\section{Primer design and synthesis}

Primers were designed with Primer 5.0 software using Sus scrofa sequences from the NCBI database and synthesized by Shanghai Shenggong Bioengineering Co. Ltd. All primer sequences are listed in Table 1.

\section{Real-time PCR}

Real-time PCR was performed on an ABI7500 instrument (Life Technologies, Gaithersburg, MD, USA); each experiment was performed six times. Reactions were performed in a $20-\mu 1$ reaction volume containing $20 \mu \mathrm{M}$ of each primer, $10 \mu \mathrm{l}$ SYBR Green Real-Time PCR Master Mix (TOYOBO, Japan), and $1 \mu \mathrm{l}$ cDNA template. PCR cycling conditions were: $94^{\circ} \mathrm{C}, 5 \mathrm{~min}$; 38 cycles each of $94^{\circ} \mathrm{C}$ for $30 \mathrm{~s}$; $59^{\circ} \mathrm{C}$ for $30 \mathrm{~s} ; 72^{\circ} \mathrm{C}$ for $30 \mathrm{~s}$; and final extension at $72^{\circ} \mathrm{C}$ for $10 \mathrm{~min}$.

\section{Western blotting}

Cells were lysed using TRIzol reagent, and the concentration of extracted proteins was measured by the BCA standard method (Krieg et al., 2005). Twenty micrograms of protein was separated by SDS-PAGE and transferred to PVDF membranes. Primary antibodies (1:200) (primary antibodies: DMT1, PEPT1, GAPDH; and mouse monoclonal IgG1 were from Santa Cruz Biotechnology, Heidelberg, Germany) were added, followed by HRPconjugated goat anti-mouse antibody $(1: 5,000)$. Proteins were visualized by chemiluminescence (FluorChemM, ProteinSimple, USA). Densitometry was performed with Image J 1.44P software. Results are expressed relative to GAPDH.

\section{Statistical analyses}

Data are expressed as mean \pm standard deviation (SD). After a test of assumptions of normality and equal variance, data analysis was performed with SPSS 17.0 software with three-way analysis of variance (factors: iron source, time, concentration) and the Student-Neuman-Keuls post hoc test was applied to make individual comparisons. Results were considered statistically significant at $P<0.05$ and $P<0.01$.

\section{Results}

\section{Influence of ferrous bisglycinate on PepT1 mRNA expression}

Compared with ferrous sulphate, PepT1 transcript expression in ferrous bisglycinate groups was significantly higher in treatments with $0.5,1 \mathrm{mmol} \cdot 1^{-1}$ iron at $24 \mathrm{~h}$ (Figure $1 \mathrm{~A} ; P<0.05$ ) and $36 \mathrm{~h}$ (Figure $1 \mathrm{~A} ; P<0.01$ ). The mRNA expression of PepT1 was significantly lower at $12 \mathrm{~h}$ than $24 \mathrm{~h}$ and $36 \mathrm{~h}$ in the treatments with iron concentrations of 0.5 and $1 \mathrm{mmol} \cdot 1^{-1}(P<0.01)$.

\section{Influence of ferrous bisglycinate on DMT1 mRNA expression}

There was no significant difference between ferrous bisglycinate and ferrous sulphate. The mRNA expression of DMT1 was significantly lower at $12 \mathrm{~h}$ than at $24 \mathrm{~h}$ and $36 \mathrm{~h}$ in the treatments with an iron concentration of $2 \mathrm{mmol} \cdot \mathrm{1}^{-1}$.

\section{Influence of ferrous bisglycinate on ferritin mRNA expression}

Ferritin mRNA expression was significantly higher in the presence of ferrous bisglycinate $(24 \mathrm{~h}$, $\left.1 \mathrm{mmol} \cdot 1^{-1} ; 36 \mathrm{~h}, 0.5 \mathrm{mmol} \cdot 1^{-1}\right)$ than in the presence of ferrous sulphate $(P<0.05)$. At the same iron concentrations, ferritin transcript expression increased 

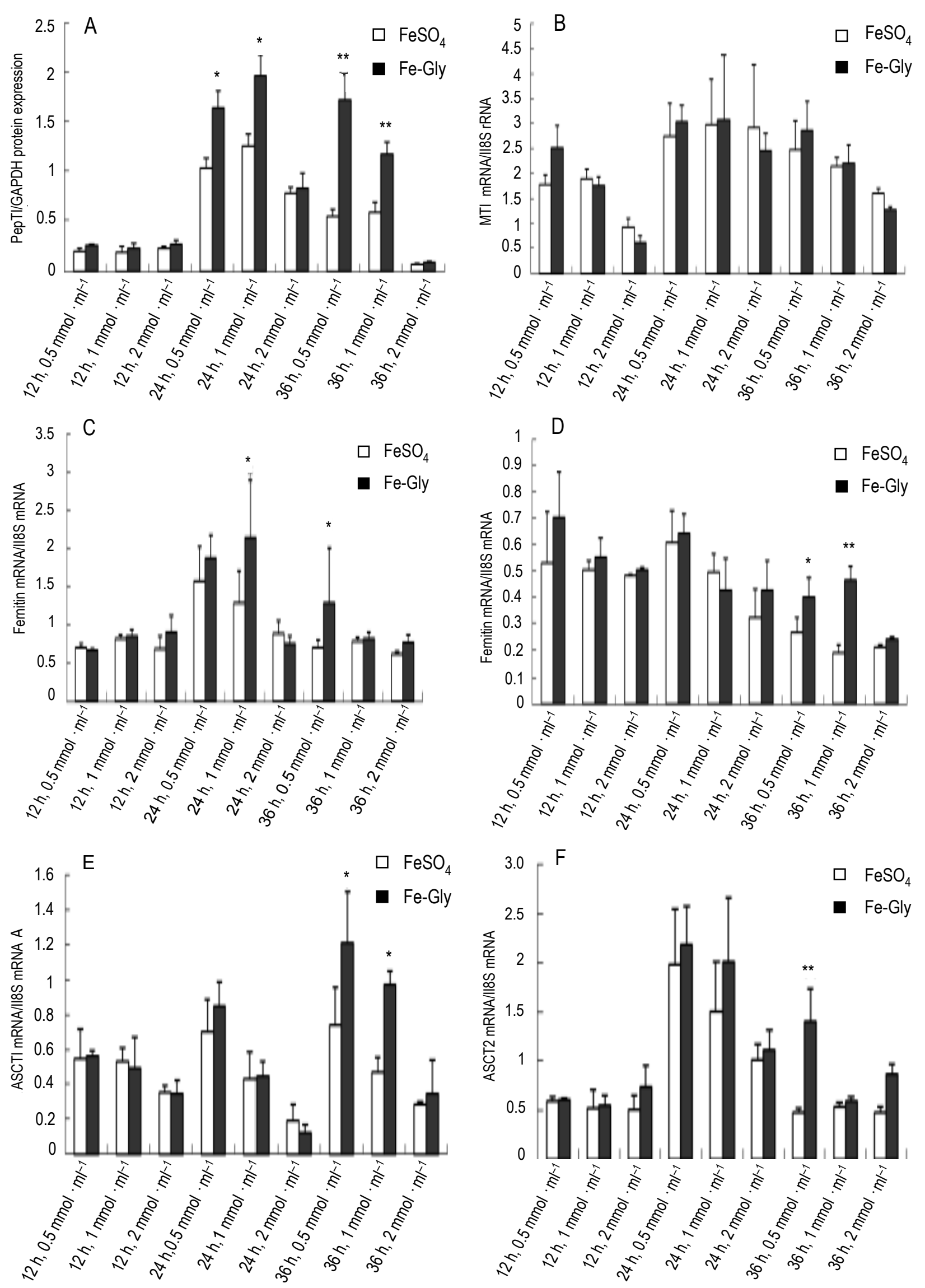

Figure 1. Influence of different iron concentrations and processing times on the relative transcript levels of cell PepT1, DMT1, ferritin, TfR, ASCT1, ASCT2 mRNA; $(n=6) ;{ }^{*}$ means significant differences between Fe sulphate and ferrous bisglycinate $(P<0.05) ;{ }^{* *}$ means that the difference was very significant between Fe sulphate and ferrous bisglycinate $(P<0.01)$ 
up to $24 \mathrm{~h}$ and then decreased at $36 \mathrm{~h}$ (Figure 1C; $P<0.05)$. Expression of ferritin was significantly lower in $2 \mathrm{mmol} \cdot 1^{-1}$ after $24 \mathrm{~h}$ compared with treatments with 0.5 and $1 \mathrm{mmol} \cdot 1^{-1}$.

\section{Influence of ferrous bisglycinate on TfR mRNA expression}

At $36 \mathrm{~h}, \mathrm{TfR}$ mRNA expression was higher in the presence of $0.5 \mathrm{mmol} \cdot 1^{-1}$ and $1 \mathrm{mmol} \cdot 1^{-1}$ ferrous bisglycinate than in the presence of ferrous sulphate $(P<0.05)$. Processing time had no effect on expression of TfR, and long-term (36 h) incubation with high-concentration iron $\left(2 \mathrm{mmol} \cdot \mathrm{1}^{-1}\right)$ yielded the lowest TfR mRNA expression compared with other groups (Figure 1D).
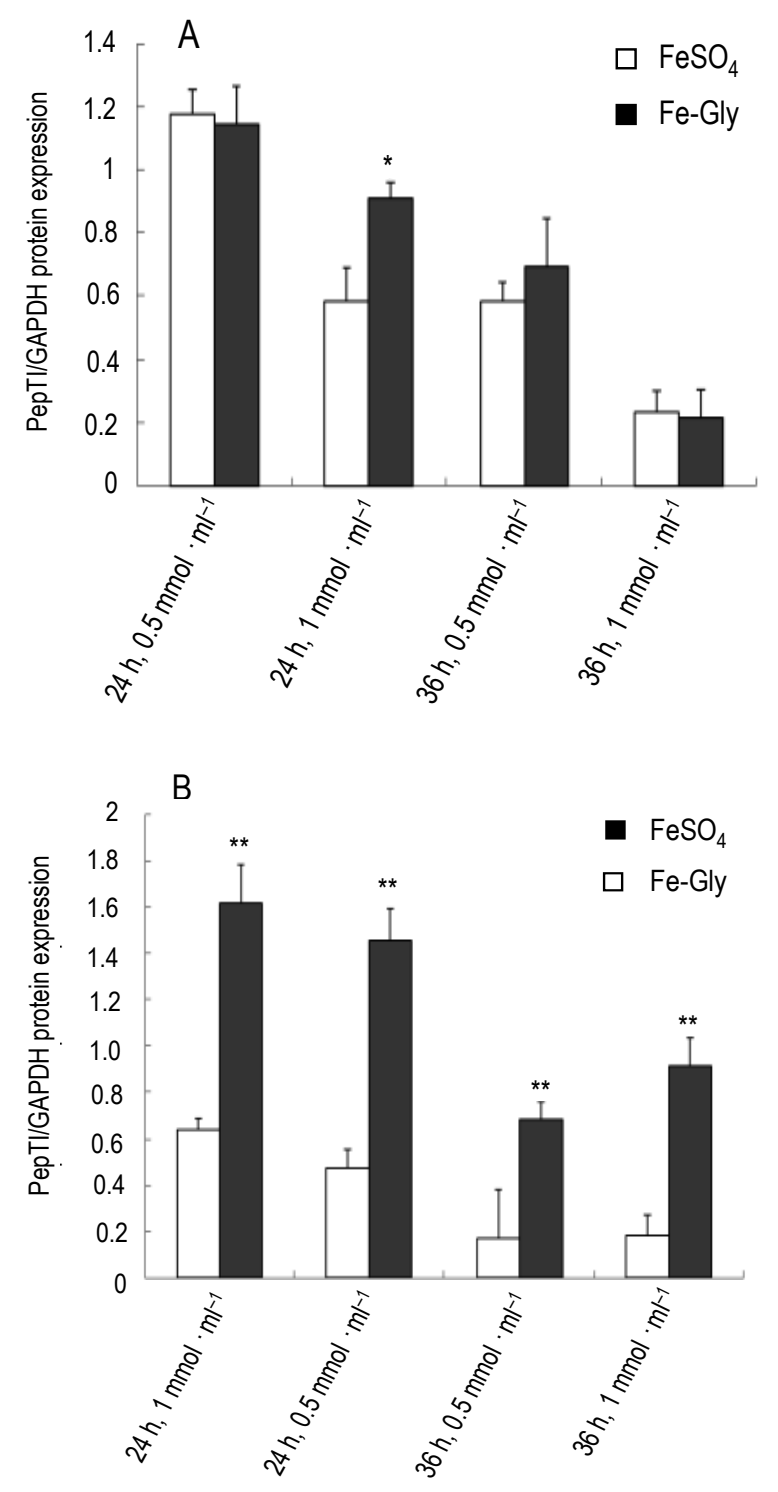

Figure 2. Influence of ferrous sulphate and ferrous bisglycinate on DMT1 and PepT1 protein expression; values are DMT1/ GAPDH and PepT1/ GAPDH ratios; * indicate significant differences between Fe sulphate and ferrous bisglycinate $(P<0.05)$; ** indicate very significant differences between $\mathrm{Fe}$ sulphate and ferrous bisglycinate $(P<0.01)$

\section{Influence of ferrous bisglycinate on ASCT1 mRNA expression}

ASCT1 mRNA expression at $36 \mathrm{~h}$ was significantly higher in the presence of $0.5 \mathrm{mmol} \cdot 1^{-1}$ and $1 \mathrm{mmol} \cdot 1^{-1}$ ferrous bisglycinate than in the presence of ferrous sulphate $(P<0.05)$.

\section{Influence of ferrous bisglycinate on ASCT2 mRNA expression}

ASCT2 mRNA expression was significantly higher in the presence of ferrous bisglycinate than in the presence of ferrous sulphate at $36 \mathrm{~h}$ and 0.5 $\mathrm{mmol} \cdot \mathrm{1}^{-1}(P<0.01)$, but no significant differences were found in the other groups. Over time, mRNA expression of ASCT2 increased from $12 \mathrm{~h}$ to $24 \mathrm{~h}$, and then decreased at $36 \mathrm{~h}$ in the treatments with 0.5 and $1 \mathrm{mmol} \cdot 1^{-1}$ iron concentrations $(P<0.05)$.

\section{Influence of ferrous bisglycinate on DMT1 and PepT1 protein expression}

DMT1 protein expression was significantly promoted in the ferrous bisglycinate group than ferrous sulphate in the $24 \mathrm{~h}, 1 \mathrm{mmol} \cdot 1^{-1}$ treatment (Figure $2 \mathrm{~A} ; P<0.05)$. Compared with ferrous sulphate, expression of PepT1 protein was significantly higher in the ferrous bisglycinate groups in all treatments (Figure 2B; $P<0.01$ ).

\section{Discussion}

Ferric ion is reduced to ferrous ion at the brush border membrane of the duodenum before being transported into the intestinal epithelial cells via DMT1 (Collins et al., 2005). In cells, iron is stored in the form of ferritin or it can penetrate through the basal-cell membrane via ferroportin. After being transported out of the membrane, iron is distributed through tissues along with transferrin, which is an important extracellular transporter (Collins et al., 2005). In this study, DMT1 protein expression was significantly higher in the ferrous bisglycinate groups than in the ferrous sulphate groups when the treatment concentration was $1 \mathrm{mmol} \cdot \mathrm{l}^{-1}$ and treatment time was $24 \mathrm{~h}$, but there were no significant differences in the other groups. As it is the main iron transport protein in intestinal epithelial cells, changes in the DMT1 expression can be considered as indicative of iron absorption in the intestine (Fleming et al., 1998). Therefore, to a certain extent our data implies that ferrous ion absorption at IPEC cells could be improved by ferrous bisglycinate under optimal conditions. There were no differences in DMT1 transcription levels between the ferrous 
bisglycinate and ferrous sulphate groups, because the regulation of DMT1 by ferrous bisglycinate occurs probably only during translation.

Besides DMT1, TfR and ferritin also play important roles in iron absorption in the intestine. DMT1 has two functional isomers, one of which contains a single iron reaction element (IRE) in $3^{\prime}$-UTR and is bound by IRP (iron-regulatory proteins) in vitro; the other isomer lacks 3'-UTR (Gárate and Núñez, 2000). Iron absorption is dependent on iron concentrations in the epithelial cells of the intestine (Ludwiczek et al., 2004). It has been recognized that a high concentration of iron could reduce the combination of IRP/IRE, thus reducing the stability of DMT1 mRNA and further, affecting iron absorption. When iron is depleted in cells, IRPs inhibit ferritin expression and induce TfR expression (Gárate and Núñez, 2000). In our study, mRNA expression of TfR was significantly higher in the ferrous bisglycinate groups than in the ferrous sulphate ones when the treatment concentrations were 0.5 and $1 \mathrm{mmol} \cdot 1^{-1}$, and treatment time was $24 \mathrm{~h}$, implying that the iron concentration within IPEC cells was higher in the ferrous bisglycinate groups, which could be a result of more iron being transported from outside into IPEC cells via DMT1. Higher mRNA expression of TfR was induced by increased iron concentrations within IPEC cells in the ferrous bisglycinate groups in order to maintain cell iron balance. Consistently with TfR, expression of mRNA for ferritin, which is the main storage form in cells, showed a significant increase in the ferrous bisglycinate groups $\left(24 \mathrm{~h}, 1 \mathrm{mmol} \cdot 1^{-1} ; 36 \mathrm{~h}, 0.5 \mathrm{mmol} \cdot 1^{-1}\right)$, also indicating increased iron absorption in IPEC cells, which might be attributed to higher expression of DMT1. We think that the iron concentration in IPEC cells gradually increased with the time, but that it was transported out of the cells to prevent iron overload when its concentration exceed the cell's maximal needs. In the current study, expression of ferritin mRNA increased from $12 \mathrm{~h}$ to $24 \mathrm{~h}$ and then decreased at $36 \mathrm{~h}$. This might indicate that the iron concentration reached the highest level at $24 \mathrm{~h}$ and needed to be down-regulated to prevent overload.

Another interesting finding in our study was that PepT1 mRNA levels and protein expression were higher in the presence of ferrous bisglycinate than ferrous sulphate. Iron ions from ferrous bisglycinate can be dissolved in the stomach or duodenum and become part of the non-haeme-iron pool, where they need to compete with ferrous sulphate for absorption because they share DMT1 transport into cells.
There is, however, no competition if ferrous bisglycinate was absorbed in the form of haeme iron via the PepT1 transporter (Pizarro et al., 2002). A previous study reported that ferrous bisglycinate was absorbed more easily than ferrous sulphate (Pineda and Ashmead, 2001). In men without anaemia, ferrous bisglycinate was fully absorbed in comparison with ferrous sulphate present in pure maize food (Bovell-Benjamin et al., 2000). In a mouse intestinal ligation model, iron is transported from the mucosa to the blood not only in the form of an iron ion or chelate, but also in low-molecular-weight ferropolymers (Terato and Yoshino, 1973). In our study, the increased mRNA and protein expression of PepT1 in the ferrous bisglycinate groups indicated that the transport of ferrous bisglycinate was associated with PepT1, which may be one of the important reasons that ferrous bisglycinate can be absorbed more easily than ferrous sulphate.

The $\mathrm{Na}^{+}$-dependent neutral amino acid transport system, ASC, is expressed in the brush border membrane of intestinal epithelial cells (Palacin et al., 1998). ASCT1 and ASCT2 mediate glycine through the brush border membrane. ASCT2 is a broad-spectrum neutral amino acid carrier driven by the cross-membrane $\mathrm{Na}^{+}$concentration gradient (Zerangue and Kavanaugh, 1996; Broer et al., 1999). Its main function is to transport neutral amino acids, such as glutamine and asparagine (Bode, 2001). In our study, we found that both the expression of ASCT1 and ASCT2 were increased in the ferrous bisglycinate $1 \mathrm{mmol} \cdot 1^{-1}$ treatment group after $36 \mathrm{~h}$. It is possible that ferrous bisglycinate is partially dissolved to release glycine and the ferrous ion, which leads to an increased glycine concentration and induces expression of ASCT1 and ASCT2.

In summary, the results of the current study indicate that both DMT1 and PepT1 transporters modulate absorption of ferrous bisglycinate in IPEC cells, and that the more effective absorption of ferrous bisglycinate is associated with greater expression of DMT1 and PepT1, which provides a theoretical basic for the use of ferrous bisglycinate in animal/human nutrition.

\section{Acknowledgements}

We are grateful to Shandong Heshi Group Co. Ltd. for providing ferrous bisglycinate, Professor Guoyao Wu from Texas A\&M University for providing IPEC-1 cells, and Xiu-Qi Wang for laboratory support. 


\section{References}

Andrews N.C., 1999. Disorders of iron metabolism. N. Engl. J. Med. 341, 1986-1995

Ashmead H., 1991. Comparative intestinal absorption and subsequent metabolism of metal amino acid chelates and inorganic metal salts. Biol. Tr. Elem. Res. 306-319

Avissar N.E., Ziegler T.R., Wang H.T. et al., 2001. Growth factors regulation of rabbit sodium-dependent neutral amino acid transporter ATB0 and oligopeptide transporter 1 mRNAs expression after enterectomy. Jpen-Parenter Enter. 25, 65-72

Bode B.P., 2001. Recent molecular advances in mammalian glutamine transport. J. Nutr. 131, 2475S-2485S

Bovell-Benjamin A.C., Viteri F.E., Allen L.H. et al., 2000. Iron absorption from ferrous bisglycinate and ferric trisglycinate in whole maize is regulated by iron status. Amer. J. Clin. Nutr. 71, 1563-1569

Broer A., Brookes N., Ganapathy V. et al., 1999. The astroglial ASCT2 amino acid transporter as a mediator of glutamine efflux. J. Neurochem. 73, 2184-2194

Cocato M.L., Trindade Neto M.A. da, Berto D.A. et al., 2008. Bioavailability of iron in different compounds for piglets weaned at 21 days old. Rev. Bras. Zootecn. 37, 2129-2135

Collins J.F., Franck C.A., Kowdley K.V. et al., 2005. Identification of differentially expressed genes in response to dietary iron deprivation in rat duodenum. Amer. J. Physiol-Gastrointest. L. 288, G964-G971

Ettle T., Schlegel P., Roth F.X., 2008. Investigations on iron bioavailability of different sources and supply levels in piglets. J. Anim. Physiol. Anim. Nutr. 92, 35-43

Ezquer F., Nunez M. T., Rojas A. et al., 2006. Hereditary hemochromatosis: an opportunity for gene therapy. Biol. Res. 39, 113-24

Fairweather-Tait S.J., Fox T.E., Wharf S.G., Ghani N.A., 1992. A preliminary study of the bio availability of iron-and zinc-glycine chelates. Food Addit. Contam. 9, 97-101

Fleming M.D., Romano M.A., Su M.A. et al., 1998. Nramp2 is mutated in the anemic Belgrade (b) rat: evidence of a role for Nramp2 in endosomal iron transport. Proc. Nat. Acad. Sci. USA 95 1148-1153

Fleming M.D., Trenor C.C., Su M.A. et al., 1997. Microcytic anaemia mice have a mutation in Nramp2, a candidate iron transporter gene. Nat. Genet. 16, 383-386

Fox T.E., Eagles J., Fairweather-Tait S.J., 1998. Bioavailability of iron glycine as a fortificant in infant foods. Amer. J. Clin. Nutr. 67, 664-668

Gárate M.A., Núñez M.T., 2000. Overexpression of the ferritin ironresponsive element decreases the labile iron pool and abolishes the regulation of iron absorption by intestinal epithelial (Caco-2) cells. J. Biol. Chem. 275, 1651-1655

Gunshin H., Mackenzie B., Berger U.V. et al.,1997. Cloning and characterization of a mammalian proton-coupled metal-ion transporter. Nature $388,482-488$

Hubert N., Hentze M.W., 2002. Previously uncharacterized isoforms of divalent metal transporter (DMT)-1: implications for regulation and cellular function. Proc. Nat. Acad. Sci. USA 99, $12345-12350$

Kanai Y., Hediger M.A., 1992. Primary structure and functional characterization of a high-affinity glutamate transporter. Nature 360 , $467-471$
Krasucki W., Orlicki Ł., 2008. Effect of various iron preparations in the rearing of piglets. Med. weter. 64, 1037-1042

Krieg R.C., Dong Y., Schwamborn K. et al., 2005. Protein quantification and its tolerance for different interfering reagents using the BCA-method with regard to 2D SDS PAGE. J. Biochem. Biophys. Meth. 65, 13-19

Lipinski P., Starzynski R.R., Canonne-Hergaux F. et al., 2010. Benefits and risks of iron supplementation in anemic neonatal pigs. Amer. J. Pathol. 177, 1233-1243

Lowe J.A., Wiseman J., Cole D.J., 1994. Absorption and retention of zinc when administered as an amino-acid chelate in the dog. J. Nutr. 124, 2572S-2574S

Ludwiczek S., Theurl I., Artner-Dworzak E. et al., 2004. Duodenal HFE expression and hepcidin levels determine body iron homeostasis: modulation by genetic diversity and dietary iron availability. J. Molecular Med.-JMM 82, 373-382

Mazariegos D.I., Pizarro F., Olivares M. et al., 2004. The mechanisms for regulating absorption of $\mathrm{Fe}$ bis-glycine chelate and $\mathrm{Fe}$ ascorbate in Caco-2 cells are similar. J. Nutr. 134, 395-398

McKie A.T., Barrow D., Latunde-Dada G.O. et al., 2001. An iron-regulated ferric reductase associated with the absorption of dietary iron. Science 291, 1755-1759

Nicolas G., Bennoun M., Devaux I. et al., 2001. Lack of hepcidin gene expression and severe tissue iron overload in upstream stimulatory factor 2 (USF2) knockout mice. Proc. Nat. Acad. Sci. USA 98, 8780-8785

Nicolas G., Bennoun M., Porteu A. et al., 2002. Severe iron deficiency anemia in transgenic mice expressing liver hepcidin. Proc. Nat. Acad. Sci. USA 99, 4596-4601

Palacin M., Estevez R., Bertran J. et al., 1998. Molecular biology of mammalian plasma membrane amino acid transporters. Physiol. Rev. 78 , 969-1054

Pineda O., Ashmead H.D., 2001. Effectiveness of treatment of irondeficiency anemia in infants and young children with ferrous bis-glycinate chelate. Nutrition 17, 381-384

Pineda O., Wayne Ashmead H.D., Perez J.M. et al., 1994. Effectiveness of iron amino acid chelate on the treatment of iron deficiency anemia in adolescents. J. Appl. Nutr. 46, 2-13

Pizarro F., Olivares M., Hertrampf E. et al., 2002. Iron bis-glycine chelate competes for the nonheme-iron absorption pathway. Amer. J. Clin. Nutr. 76, 577-581

Starzynski R.R., Lipinski P., Drapier J.C. et al., 2005. Down-regulation of iron regulatory protein 1 activities and expression in superoxide dismutase 1 knock-out mice is not associated with alterations in iron metabolism. J. Biol. Chem. 280, 4207-4212

Tam N.F.Y., Yao M.W.Y., 1999. Three digestion methods to determine concentrations of $\mathrm{Cu}, \mathrm{Zn}, \mathrm{Cd}, \mathrm{Ni}, \mathrm{Pb}, \mathrm{Cr}, \mathrm{Mn}$, and $\mathrm{Fe}$ in mangrove sediments from Sai Keng, Chek Keng, and Sha Tau Kok, Hong Kong. Bull. Environ. Contam. Toxicol. 62, 708-716

Terato K., Yoshino Y., 1973. Studies on iron absorption. Digest. Dis. $18,121-128$

Yeung C.K., Glahn R.P., Miller D.D., 2005. Inhibition of iron uptake from iron salts and chelates by divalent metal cations in intestinal epithelial cells. J. Agr. Food Chem. 53, 132-136

Zerangue N., Kavanaugh M.P., 1996. ASCT-1 is a neutral amino acid exchanger with chloride channel activity. J. Biol. Chem. 271, 27991-27994 